\title{
Endogenous endophthalmitis due to Kingella Kingae infectious endocarditis
}

\author{
Endoftalmite endógena por endocardite \\ infecciosa devido a Kingella Kingae
}

Paula Rabelo Halfeld Mendonça' https://orcid.org/0000-0002-7057-2632

Mirela Luna Santana Gomes ${ }^{2}$ https://orcid.org/0000-0003-1626-4425

Vivian Passini Guimarães Gomes¹ https://orcid.org/0000-0002-9296-0644

Maria da Conceição Frasson Correa da Silva² https://orcid.org/0000-0002-1250-3575

Sarah Cristina Zanghellini Rück| ${ }^{3}$ https://orcid.org/0000-0002-5413-9847

Carolina Saliba de Freitas ${ }^{1}$ https://orcid.org/0000-0002-0785-8988

\begin{abstract}
This report presents a rare case of endogenous endophthalmitis due to Kingella kingae infectious endocarditis. Endogenous endophthalmitis is a rare condition that has a systemic underlying cause, with hematogenic dissemination of a pathogen that will eventually reach and infect the eye. In this article, we present a case of a 54-year-old woman with fever, chills and decreased visual acuity and pain in the right eye. The slit-lamp exam showed conjunctival injection, anterior chamber reaction with a great amount of fibrinous material obscuring her visual axis. Ultrasound echography revealed profuse exudates and scarce membranous formation in the posterior segment. Blood culture was positive for Kingella kingae, and the patient was treated with intravenous ceftriaxone, along with topic dexamethasone and mydriatic. After 15 days of intravenous antibiotic therapy, the patient exhibited best visual acuity of 20/60. Endogenous endophthalmitis is an ocular emergency that demands quick diagnosis and aggressive intervention in order to preserve vision. Therefore, it is important to recognize its signs and symptoms with no retard.
\end{abstract}

Keywords: Bacterial endocarditis; Abscess; Eye infections; Endophthalmitis; Kingella kingae

\section{RESUMO}

O presente relato apresenta um raro caso de endoftalmite endógena por endocardite devido à Kingella kingae. Endoftalmite endógena é uma doença pouco comum com uma causa sistêmica subjacente. A disseminação hematogênica de um microrganismo infeccioso leva à infecção ocular. Nesse artigo, apresentamos o caso de uma mulher com 54 anos, febre, calafrios, baixa da acuidade visual e dor em olho direito. Ao exame na lâmpada de fenda apresentava injeção conjuntival, reação de câmara anterior e acúmulo de fibrina no eixo visual. Ultrassonografia revelou exsudatos profusos e escassa formação membranosa em segmento posterior.A hemocultura foi positiva para Kingella kingae e a paciente foi tratada com ceftriaxone venoso conjuntamente com dexametasona e midriático tópicos. Após 15 dias de terapia antibiótica endovenosa, a paciente apresentou acuidade visual corrigida de 20/60. Endoftalmite endógena é uma emergência ocular que demanda rápido diagnóstico e intervenção agressiva para preservar a visão. Portanto, é importante o reconhecimento precoce dos sinais e sintomas.

Descritores: Endocardite bacteriana; Abscesso; Infecções oculares; Endoftalmite; Kingella kingae

\footnotetext{
'Universidade Federal de Minas Gerais, Belo Horizonte, MG, Brazil.

${ }^{2}$ Retinal Departament, Universidade Federal de Minas Gerais, Belo Horizonte, MG, Brazil.

${ }^{3}$ Departament of Forensic Medicine and Psychiatry, Federal University of Paraná, Curitiba, PR, Brazil.
}

Project number and institution responsible for the approval of the Research Ethics Committee: CAAE 01915218.8.0000.5149 Universidade Federal de Minas Gerais.

The authors declare no conflict of interest

Received for publication 27/2/2020 - Accepted for publication 10/7/2020. 


\section{INTRODUCTION}

$\mathbf{E}$ ndogenous endophthalmitis is a severe ocular condition caused by the installation of a pathogen in the eye through the choroidal blood supply, mostly in immunosuppressed people with an infectious site. ${ }^{(1)}$ The disease manifests usually unilaterally with blurred sight, pain and eye redness. ${ }^{(2)} \mathrm{A}$ nearly recognition is essential due to poor visual prognosis, and treatment involves systemic and intravitreal antibiotic therapy along with vitrectomy. ${ }^{(1,2)}$ In this article, we present a rare clinical case of a middle-aged female patient with endogenous endophthalmitis due to Kingella Kingae infectious endocarditis, and achieved good visual results only with systemic therapy.

\section{Case report}

A 54-year-old woman was admitted to our hospital in 05.29.19 with fever, chills, dental abscess and echocardiography (TTE) suggesting a vegetation in the mitral valve. Past medical history included a mitral valve replacement in April/2018, hypertension and dyslipidemia. She was in use of losartan, hydrochlorothiazide and rosuvastatin.

Blood cultures were collected and sent to the laboratory for analysis. Empirical treatment with intravenous ampicillin, gentamycin and oxacillin was prompt started due to the risk of possible endocarditis secondary to a dental abscess.

The patient was referred to the ophthalmology service for decreased visual acuity, redness and pain in her right eye. She denied ocular trauma or previous eye surgery.

The visual acuity was hand motion and 20/20 in the right and left eyes, respectively.

Right eye slit-lamp examination revealed conjunctival injection, corneal edema, $3+/ 4$ anterior chamber cells and fibrinous material on her visual axis. The fibrinous precipitate prevented the fundus view on her right eye. Her left eye had a normal exam.

Endogenous endophthalmitis was the presumed diagnosis and the patient was treated with intravenous antimicrobials, dexamethasone and tropicamide, both topics.

A careful clinical evaluation led to the decision to defer diagnostic vitreal biopsy and intravitreal antibiotic therapy to first confirm and properly treat the endocarditis.

A transesophageal echocardiogram was carried out on the subsequent day and confirmed a mitral valvular mass with $8 \times 13 \mathrm{~mm}$

Blood cultures grew Kingella Kingae, sensitive to ceftriaxone, on 06.01.19. At this point, endocarditis was validated by the Modified Duke Criteria for endocarditis. The patient had two major criteria: positive blood culture with typical organism from 2 different blood cultures and a positive echocardiogram. Antibiotic treatment was then changed to intravenous ceftriaxone.

A dental abscess drainage was performed in 06.01.19.

On the next day, right eye echography revealed no retinal detachment, profuse exudates and scarce membranous formations, corresponding to endophthalmitis in resolution (Figure1).

Pain in the right eye was relieved. Visual acuity was 20/125 and 20/20 in the right and left eyes, respectively.

The right eye anterior segment showed absence of conjunctival hyperemia, multiple posterior synechiae, $3+/ 4$ anterior chamber cells and a considerable decrease in the fibrinous material although it still prevented a fundoscopic evaluation (Figure 2).

Therefore, antibiotic intravitreal injection was no longer recommended. Left eye examination had no alterations.
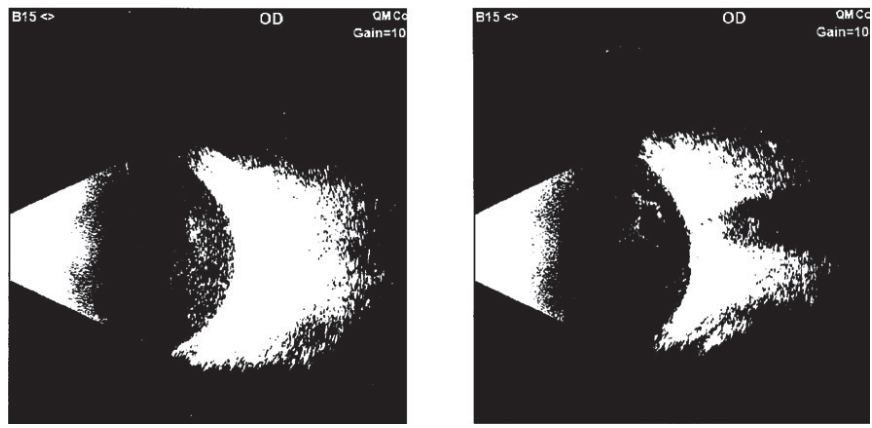

Figure 1: Ultrasound imaging of the right eye with profuse vitreous exsudates and scarce membranous formation, corresponding to endophthalmitis in resolution. No retinal detachment was identified.

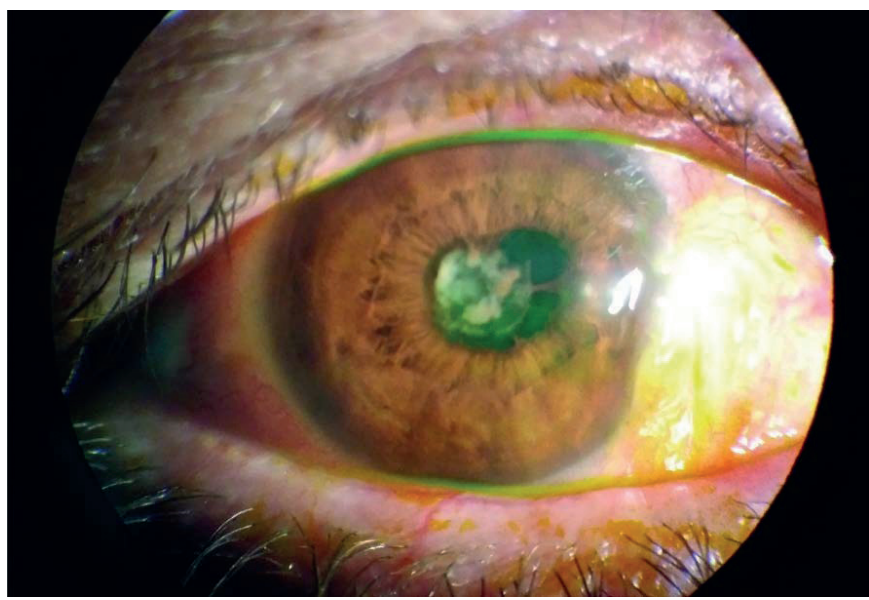

Figure 2: Slit-lamp photo of the right eye after 6 days of intravenous antimicrobial treatment. Anterior segment with lessened hyperemia, anterior chamber reaction $3+/ 4+$, fibrinous material deposit on the visual axis and multiple posterior synechiae.

Four cycles of mydriatics intercalated with dexamethasone ophthalmic solution were carried out to break-up the posterior synechiae.

On 06.12.19, the patient exhibited best visual acuity of 20/60 and 20/20 in the right and left eyes, respectively. Slit-lamp biomicroscopic evaluation of the right eye showed a thin and translucent conjunctiva, transparent cornea, $1+/ 4$ of white blood cells in the aqueous humor and fibrin residuum in the anterior chamber. Left eye exam remained unremarkable.

\section{Discussion}

Endophthalmitis is an unusual but severe type of ocular inflammation. According to the transmission route of the infectious agent, it is classified in exogenous and endogenous. The first one is more frequent, being generally associated with intraocular procedures or trauma, whilst the second one occurs when the microorganisms are hematogenously spread into the eye from a distant focus of infection. . $^{(1,2)}$

Although it is caused by hematogenous dissemination, endogenous endophthalmitis tends to develop unilaterally, ${ }^{(2)}$ with the right eye more commonly affected, possibly due to the more proximal and direct arterial route from the heart to the right carotid artery. ${ }^{(3)}$ Our case confirms these observations.

Endogenous bacterial endophthalmitis is an uncommon entity that comprises $2-15 \%$ of all cases of endophthalmitis. ${ }^{(2)}$ Our 
Table 1

Review of literature of HACEK endogenous endophthalmitis in the last 14 years

\begin{tabular}{|c|c|}
\hline Authors Year & Shum, et al \\
\hline & $2015^{(4)}$ \\
\hline Age/gender & 56 year old, male \\
\hline Systemic history & Kidney Abscess \\
\hline Initial BCVA & $20 / 200$ \\
\hline Clinical presentation & $\begin{array}{l}\text { Small inflamatory cells in the vitreous, } \\
\text { Slightly blurring of disc and macula. } \\
\text { Retinal infiltrate with scattered dot haemorrhages. }\end{array}$ \\
\hline Blood culture & Aggregatibacteraphrophilus \\
\hline Treatment & $\begin{array}{c}\text { Intravitreal injection of vancomycin and ceftazidime. } \\
\text { Pars plana vitrectomy. }\end{array}$ \\
\hline
\end{tabular}

Final Outcome $20 / 30$ Unreported

report is an exceptionally rare example of endogenous endophthalmitis due to K. kingae infective endocarditis. After an extensive search in PubMed database, only two articles were found in the last 14 years with HACEK organisms associated with endogenous endophthalmitis. Both authors found Aggregatibacter spp related to the infection (Table1). There were no articles found correlating Kingella infectious endocarditis with endogenous endophthalmitis in adults. ${ }^{(4,5)}$

$\mathrm{K}$. Kingae is a facultative anaerobic Gram-negative coccobacillus that has been reported as a normal inhabitant of the oropharynx. Hematogenic dissemination is probably caused by mucosal damage and can lead to distant focal infections. Poor dental hygiene and dental extractions have been related to initial infection. ${ }^{(6)}$ Our patient had a dental abscess as an important risk factor for endocarditis. That last one was thought to be the cause of endophthalmitis and was reinforced by growth of K. kingae in blood cultures.

Collecting cultures, from blood and intraocular fluids, is important in attempt to identify the pathogenic microorganism and to guide treatment. ${ }^{(2)}$ Due to poor systemic conditions, only blood cultures were available in our case.

Although, there is not a treatment protocol for $\mathrm{K}$. kingae endophthalmitis, ${ }^{(7)}$ it is generally susceptible to $\beta$-lactams alone or associated with aminoglycoside. ${ }^{(6)}$ The patient was treated with intravenous ceftriaxone and presented a final visual acuity of 20/60 with resolution of endocarditis.

Visual outcomes are usually poor with endogenous endophthalmitis due to early retinal involvement. ${ }^{(8)}$ Parenteral and intravitreal antimicrobial agents are generally the treatment approach,however,underlyingseveresystemicdiseaseisusuallypresentandmayrestrain intravitreal treatment or vitrectomy. ${ }^{(9)}$ It is well known that ceftriaxone crosses the blood- brain and blood-ocular barriers, and prolonged aqueous humour levels are probably related to its prolonged plasma levels. ${ }^{(10)}$ Our patient achieved remission with intravenous ceftriaxone, probably due to less severe ocular inflammation at presentation and promptly antibiotic treatment.

For its gravity, endogenous endophthalmitis is an ocular emergency, with reserved visual prognosis. Therefore, prompt diagnosis and aggressive treatment are central to successful management of endogenous endophthalmitis, and to preserve useful vision.

\section{RefERENCES}

1. Cunningham ET, Flynn HW, Relhan N, Zierhut M. Endogenous Endophthalmitis. Ocul Immunol Inflamm. 2018;26(4):491-5.

2. Muda R, Vayavari V, Subbiah D, Ishak H, Adnan A, Mohamed SO. Endogenous endophthalmitis: a 9-year retrospective study at a tertiary referral hospital in Malaysia. J Ophthalmic Inflamm Infect. 2018 Oct; $8(1): 14$

3. Sheu SJ. Endophthalmitis. Korean J Ophthalmol. 2017;31(4):283-9.

4. Shum JW, Tsang FC, Fung KS, Li KK. Presumed Aggregatibacter aphrophilus endogenous endophthalmitis. Int Ophthalmol. 2015;35(2):269-73.

5. Moradi P, Roberton B, Osborne R, Muhtaseb M, Graham EM, Klein $\mathrm{J}$, et al. HACEK endocarditis causing endogenous endophthalmitis and a metastatic abscess. Eye (Lond). 2006;20(2):254-5.

6. Yagupsky P. Kingellakingae: carriage, transmission, and disease. Clin Microbiol Rev. 2015;28(1):54-79.

7. Illán-Ramos M, Guillén-Martín S, Prieto-Tato LM, Cacho-Calvo JB, González-Romo F, Francisco-González L, et al. Kingella kingae como agente causal frecuente de artritis séptica en Pediatría. Rev Esp Quimioter. 2018;31(5):439-42.

8. Chen KJ, Sun MH, Chen YP,Wang NK, Wu WC, Lai CC. Endogenous Endophthalmitis Caused by Infective Endocarditis in East Asia. Ophthalmol Retina. 2019;3(4):382-4.

9. Kuo G, Lu YA, Sun WC, Chen CY, Kao HK, Lin Y, et al. Epidemiology and outcomes of Endophthalmitis in chronic dialysis patients: a 13-year experience in a tertiary referral center in Taiwan. BMC Nephrol. 2017;18(1):270-8.

10. Axelrod JL, Newton JC, Sarakhun C, Lester RD, Merhige K, Peck $\mathrm{RL}$, et al. Ceftriaxone. A new cephalosporin with aqueous humor levels effective against enterobacteriaceae. Arch Ophthalmol. 1985;103(1):71-2.

\section{Corresponding author:}

Paula Rabelo Halfeld Mendonça

Rua Bernardo Guimarães, 475/ 1504 - Bairro Funcionários

Belo Horizonte - Minas Gerais - Brazil- Zip code: 30140-086

Phone number: 055 - 31 - 99424-2094

E-mail:paula.halfeld13@gmail.com 